\title{
Religioossed ja spirituaalsed kriisid vaimse tervise valguses
}

\author{
Indrek Linnuste \\ Tartu Ülikooli humanitaarteaduste ja kunstide valdkonna \\ usuteaduskonna doktorant \\ indrek.linnuste@gmail.com
}

\begin{abstract}
Teesid: Artikli eesmärk on laiendada teadlikkust spirituaalsete kriiside teemal. Autor annab ülevaate viimase paarikümne aasta jooksul üha enam populaarsust koguva spirituaalse temaatika varjukülgedest, mis oma äärmuslikkuses võivad sattuda ka psühhiaatria huviorbiiti. Globaalses situatsioonis kiirelt arenevad ja kombineeruvad sünkretistlikud õpetused võivad küllaltki selgepiirilises ja konservatiivses meditsiinisüsteemis jääda vajaliku tähelepanuta ning abita. Spirituaalsed vajadused on inimesele omased ning sageli kerkivad need esile just ravil olles, kus on oht neid ignoreerida või koguni stigmatiseerida. Spirituaalsetel kriisidel on mitmeid variatsioone ning kannatustest ja heitluste eest ei ole kaitstud ka ennast usklikuks pidavad inimesed. Spirituaalsetes kriisides peitub isiksuslik arengupotentsiaal, kuid sageli kaasneb ka oht romantiseerida tõsiseid psühhiaatrilisi häireid ning patoloogilisi kogemusi. Artikkel aitab laiendada arusaama mitmete vaimse tervise häirete olemusest ning vaatenurga muutmine toob kaasa võimaluse mõista ja käsitleda neid vastavalt.
\end{abstract}

Märksõnad: spirituaalsus, spirituaalsed vajadused, spirituaalne kriis, vaimne tervis

\section{Sissejuhatus}

Depressioon, stress ja mitmesugused kriisid on ühelt poolt psühholoogia ja psühhiaatria uurimis- ning ravivaldkond, teisalt tavainimese jaoks lihtsalt eluga kaasaskäivad eluepisoodid, juhul kui nendega ei kaasne diagnoosid, sildid (stigmad) ja haiglasse sattumine, olgu põhjusteks lahutused, murdeiga, lein või kuriteo ohvriks langemine. Psühholoogia uurib hinge kui psüühiliste nähtuste kogumit ja on tänapäeval kaugel sellest, et eristada lisaks psüühilistele protsessidele, seisunditele ja omadustele veel midagi eraldiseisvat, vähemalt selles mõttes, nagu seda teeb teoloogia. Peale teadusliku psühholoogia on aga olemas ja alati olemas olnud argipsühholoogia, mis kujutab teoloogiadoktor Tarmo Kulmari järgi endast tavainimeste mõttekonstrukti inimesest kui olemasolevast, tajuvast, tundvast ja mõtlevast olendist, lähtudes ajastu teadmistest ja ettekujutustest (Kulmar 1998). Lühidalt on kriis elu osa, mis on seotud eelkõige indiviidiga, kuid spetsialistide (arstide, psühholoogide, terapeutide jt) tööpõllule 
toob selle vastavale kriisile antav tõlgendus inimeselt, kes sellega toime ei tule, kellel langeb elukvaliteet, kaovad tähendused ning tekib toetuse vajadus, et elus edasi minna. Kriisi tagajärjel muutub inimeste väärtussüsteem, sageli hinnatakse ümber põhimõtteid, mida seni on dogmaatiliselt kaljukindlateks peetud. Kerkivad küsimused miks mina?, miks minuga? jne.

Kindlasti on individuaalsed kriisid inimeseti väga erineva kaaluga. Ühel inimesel võib lemmiklooma surm põhjustada pika ja halvava leina, kuid teisel ei pruugi näiteks elukaaslase surm käitumismustreid nähtavalt mõjutada. On palju juhtumeid, kus inimene ei suudagi kriisi lahendada muul kombel kui enesetapuga. "Palju" all mõtlen umbkaudu miljonit inimest, kes igal aastal maailmas ise oma elu lõpetavad (Eesti-Rootsi vaimse tervise ja suitsidoloogia instituut 2008: 6). Kindlasti on nende hulgas ka spirituaalsete kriisidega seotud inimesi. Kuigi paljud autorid seostavad spirituaalsust ja religiooni enamjaolt tugeva vaimse tervise (Koenig \& McCullough et al. 2001: 78-79) ja toimetulekuga (Pargament 1997), tuleb välja tuua ka varjuküljed. Positiivse nurga alt olen vaimsust kui ressurssi inimestega töötamisel varem käsitlenud (Linnuste 2018), kuid spirituaalsusega kaasnevad ohud vaimse tervise valdkonnas pole senini kodumaistes erialaajakirjades käsitlust leidnud. Teema on aktuaalne seda enam, et ühelt poolt on eestlased väga tundlikud ühiskondlike muutuste suhtes. Sellele viitab näiteks enesetappude suur hulk 1990. aastatel ${ }^{1}$ või ka alkoholi kuritarvitamine. ${ }^{2}$ Teisalt peavad teadlased Eestit väga huvipakkuvaks religioosseks Euroopa Liidu "katselaboriks", kus kirikus käib kord nädalas vaid $2 \%$ rahvastikust, kuid samas mingisugusesse hinge või elujõu olemasolusse usub 50\% inimestest (Heelas 2013). Seega: kui Eesti sekulariseerumistendentsis on näha religioossuses jõulisi muutumisi nn uue vaimsuse ${ }^{3}$ suunas, siis vaimse tervise valdkond vajab kindlasti lisaks täiendõppele juurde ka hingehoidjaid, kes mõistavad spirituaalsete kriiside eripära, oskavad neid eristada depressioonist või psühhootilistest häiretest, on vabad eelarvamustest ega stigmatiseeri kõnealust nähtust, vaid proovivad hukkamõistmise asemel mõista.

Artikli eesmärk on anda ülevaade religioossetest ja spirituaalsetest kriisidest $^{4}$ (edaspidi R/S) ning kaasa aidata nende vabastamisele stigmadest, ühes sellega pakkuda kriisis olijatele ja olnutele äratundmist ning valgustada spetsialistidele laiemat pilti kõnealuste nähtuste kohta veidi teisest vaatepunktist. Spirituaalsus ja spirituaalsed vajadused ning nendega seonduv on järjest enam ka terviseteadustega seonduvate teadlaste huviorbiidis (Koenig 2012). Artiklis kirjeldan ja analüüsin mitmeid religiooni ja vaimsusega seotud probleeme, mis seni ei ole kajastust leidnud rahvusvahelise haiguste klassifikatsiooni (RHK) 10 diagnostilistes kriteeriumites, ning tutvustan muudatusi USA tervishoiusüsteemis, kus on esimesena hakatud nendele tähelepanu pöörama. 


\section{Spirituaalsus ja spirituaalne kriis}

Spirituaalsust saab defineerida erinevalt olenevalt sellest, kas fookuses on teaduslik uurimistöö või kliiniline praktika. Esimesel puhul on oluline konkreetsus ja täpsus, millele rajatakse uurimistöö struktuur, samas kliinilise praktilise töö jaoks on definitsiooni keskmeks pigem patsient oma individuaalsete spirituaalsete vajadustega. Näiteks David Hay ja Kate Hunt jätsid kirikus mittekäivate inimeste spirituaalsust uurides teadlikult uurimistöö käigus spirituaalsuse defineerimata, et avastada inimeste personaalset arusaama oma individuaalsest spirituaalsusest. Nende sõnul ja eeldusel on kõik inimesed spirituaalsed, keskenduti pigem inimeste maailmapildile ja elukogemusele. Spirituaalne lugu või narratiiv iseenesest on palju võimsam kui mistahes kirjapandud definitsioon (Hay \& Hunt 2000). Mõiste konkretiseerimiseks on hea jagada definitsioon osadeks ning tuua välja märksõnad ja tuumkategooriad.

Spirituaalsuse mõiste analüüsimiseks töötas Chris Cook Durhami ülikoolist läbi 265 artiklit ning leidis, et ainult $12 \%$ nendest artiklitest defineeris spirituaalsust selgesõnaliselt. $32 \%$ pakkus välja spirituaalsuse kontseptsiooni kirjelduse kaudu. $12 \%$ sidus spirituaalsuse mõiste teiste sarnaste kontseptsioonidega (the spiritually healthy person) ning $44 \%$ artiklitest jättis defineerimise välja. Cook klassifitseeris erinevate definitsioonide sisu esialgu kolmeteistkümnesse kontseptuaalsesse ossa ning leidis spirituaalsuse definitsioonile neli kõige omasemat komponenti: transtsendentsus, seotus, tuum/jõud/hing ja tähendus/ eesmärk (Cook 2004; Cook \& Powell et al. 2009).

Spirituaalsus on distinktiivne, potentsiaalselt loov, universaalne inimkogemuse dimensioon, mis tuleneb nii indiviidi sisemisest subjektiivsest teadlikkusest kui ka kogukondade, sotsiaalsete gruppide ja traditsioonide mõjust. Seda võib kogeda kui suhet millegagi, mis on intiimselt "sisemine”, immanentne ja personaalne, eneses ja teistes, ja / või kui suhet, mis on tervenisti "teine”, transtsendentne ja enesest väljaspool paiknev. Seda kogetakse fundamentaalsena või ülimat tähtsust omavana ja seostatakse seetõttu elu tähenduse, eesmärgi, tõe ja väärtustega (Forcehimes \& Tonigan 2009; Cook \& Powell et al. 2009).

Seega, kui kriisi põhjustanud kogemused ja sündmused on seotud isiklike uskumustega, religiooni, religioossete küsimustega, vaimsete praktikatega, maailmatunnetuse, eksistentsiaalsete küsimustega oma identiteedi kohta, egoüleste ja minapiire ületavate kogemustega, saame neid kokkuvõtvalt ja üldistatult nimetada spirituaalseteks kriisideks. ${ }^{5}$ 
Kriiside alla saab paigutada ka väga vastuolulised ja sageli pigem meedias ja populaarteaduslikult käsitletud teemad, nagu tulnukaröövid, surmalähedased kogemused, paranormaalsed nähtused, olgu selleks kontaktid inglitega või muude olenditega teispoolsusest (Lukoff \& Lu \& Yang 2011). Valdkond vajab kindlasti diskussiooni ning konstruktiivseid lahendusi, mitte hukkamõistu.

Tänapäevases tervishoiusüsteemis, kus rõhk on elukvaliteedil ning patsiendikesksel lähenemisel, ei tohiks ära unustada ega vältida ühtegi inimest puudutavat mõõdet. Seega on oluline koguda võimaluse korral anamneesis ka spirituaalset ajalugu (spiritual history) (Hefti \& Gomes Esperandio 2016; Puchalski \& Romer 2000).

\section{Spirituaalsed vajadused}

Spirituaalsed kriisid on sagedasti seotud inimese vaimsete vajadustega. Toimetulek ja kohanemine kannatusega on seotud patsiendi isiklike uskumuste ja spirituaalse dimensiooniga (Puchalski \& Romer 2000: 129). Et täpsustada ja piiritleda, mis on patsiendi spirituaalsed vajadused, et neid oleks võimalik ka mõõta kliinilises töös, kaardistasid psühholoogid Kathleen Galek, Kevin J. Flannelly ja nende kolleegid erinevaid vaimsusega seotud artikleid ja uurimistöid, et luua universaalne mõõtmisinstrument. Kokku leiti 339 esmast märksõna, mis haakusid spirituaalsete probleemidega. Need jaotati omakorda seitsmesse kategooriasse: 1) armastus/kuulumine/austus; 2) jumalik (divine); 3) positiivsus/tänulikkus/lootus/rahu; 4) tähendus ja eesmärk; 5) moraal ja eetika; 6) väärtuslikkus, hinnalisus (appreciation) ja ilu; 7) lahendus (resolution) ja surm (Galek \& Flannely et al. 2005).

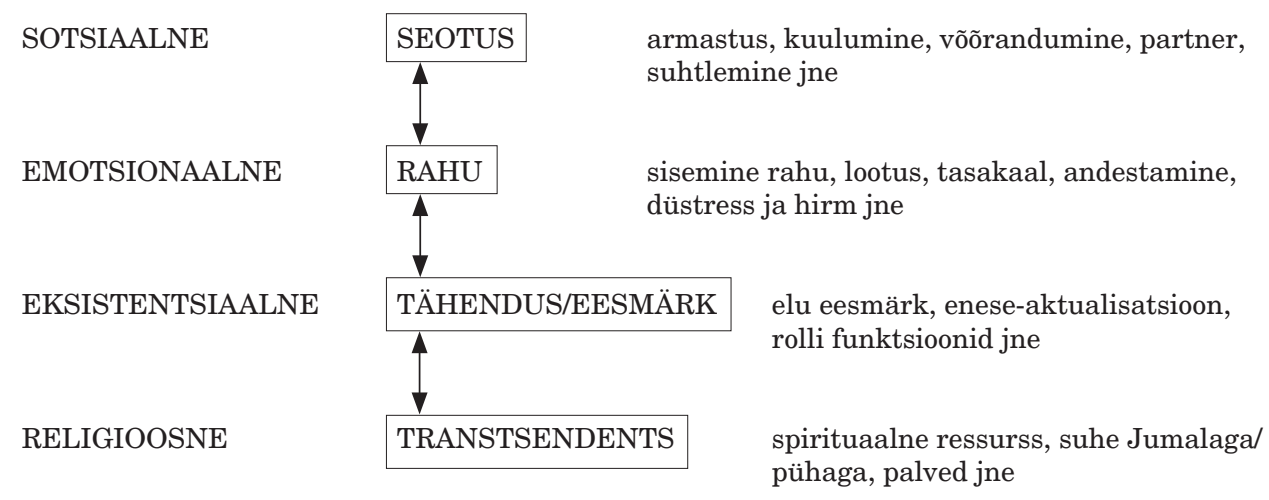

Joonis 1. Spirituaalsete vajaduste mudel (Büssing \& Koenig 2010). 
Spirituaalsed vajadused ei pea olema tingimata religioossed ning seotud Jumalaga. Inimeste vaimse tervisega tegelev Christina Puchalski selgitab, et spirituaalsusega seostuvad kõik väärtused, mis annavad inimesele sügavama, transtsendentse tähenduse ja elu eesmärgi, olgu selleks loodus, kunst, muusika, perekond või kogukond. Enne kui spirituaalsed vajadused saavad rahuldatud, on oluline nad ära tunda. Näiteks spirituaalse religioosse anamneesi kogumise teel, küsides patsiendi usulist kuuluvust, aga ka seda, mis annab talle elus lootust ja jõudu, mis on ta elulised eesmärgid ja tähendused. Vajadused on seotud nii elukaare etappide, soo kui ka identiteediga (Puchalski 2000).

Üks põhjus, miks R/S teemad ei leia ravil olles käsitlust, võib peituda mõiste religioosne lõhe taga. Religioosne lõhe (the religiosity gap) on olukord, kus patsient on rohkem usklik kui tervishoiutöötajad (Dein 2009). Lisaks arsti ja patsiendi professionaalsele suhtele toimivad raviprotsessis mitmed psühhodünaamilised ülekande suhted, mille alla saab koondada religioosse või vaimse hoiaku ja eelarvamused. Juba 1980. aastatel tehtud uuringus kirjeldasid Jerome Kroll ja William Sheehan (Kroll \& Sheehan 1989) erinevusi vaimse tervise spetsialistide ja üldrahvastiku vahel ning tõdesid, et religioon on enamikule patsientidest oluline tegur, mis vajab tähelepanuta jäänud alana süsteemset uurimistööd. Kuigi on üldteada, et usulised tavad ja religioosne kuulumine mõjutavad nii tervisekäitumist kui meditsiinilisi otsuseid (Koenig 2001), kogemustele tähenduse omistamist (Puchalski 2001), aga ka stressi ja kannatustega toimetulekut (Pargament et al. 1999), on seda vähe uuritud just haigla kontekstis. Ameerika Ühendriikides, kus Farr Curlin ja tema kolleegid viisid läbi ulatusliku uuringu 2000 arsti seas (Curlin et al. 2005), ilmnes, et arstide ning elanikonna ${ }^{6}$ hoiakud ja omadused erinevad mitmeti. Näiteks suurte probleemidega toimetulekuks arstid kaks korda tõenäolisemalt ei toetu Jumalale (61\% vs $29 \%$ ). Kuigi uuringu järgi $91 \%$ arstidest pooldab R/S teemade käsitlemist ravil olles, eriti kui need on patsiendi poolt päevakorrale tulnud, siis enamjaolt on arstid kahestunud, sest $45 \%$ ei tea, kunas ja kas on asjakohane teema tõstatamine kui patsient ise ei küsi (Curlin et al. 2006). Samuti on patsientidel eelarvamus, et arstid ei ole valmis nende probleemidest vestlema (Banin \& Suzart et al. 2014). Kolmandik küsitletud patsiendidest (küsitleti 456) soovis, et arstid küsiksid nende usulisi veendumusi visiidil, ning soov nendel teemadel suhelda oli seotud haiguse raskusastmega (MacLean \& Susi et al. 2003). Patsientide rahulolu ja elukvaliteedi uuringutest on selgunud, et paljud patsiendid soovivad haiglaravil viibides vestelda vaimsetel teemadel (McCord \& Gilchrist et al. 2004; Williams \& Meltzer et al. 2011; Banin \& Suzart 2014). Positiivselt poolelt on välja tuua Brian C. Posti ja Nathaniel G. Wade'i teostatud metanalüüs empiirilistele uuringutele (Post \& Wade 2009), kus nad töötasid PsychINFO andmebaasi kaudu läbi psühhoterapeutide töö meetodeid 
kolmes valdkonnas: religioon/spirituaalsus ja terapeudid, religioon/spirituaalsus ja kliendid, ja religioossed/spirituaalsed sekkumised. Selgus, et terapeudid on valmis käsitlema antud teemasid teraapiasessioonide ajal, ning on kliente, kellega töötades on $\mathrm{R} / \mathrm{S}$ teemade sissetoomine traditsioonilisse teraapiasessiooni osutunud efektiivseks.

Eesti tervishoiust rääkides võib tõdeda, et haiglavõrgustikes on olemas tahe arendada interdistsiplinaarset koostööd hingehoidjatega (Meel 2017). Eesti haiglate tervishoiutöötajate hulgas aastail 2015-2016 läbiviidud uuringule vastanud leiavad, et spirituaalsus ja/või religioon on tervishoiuteenustele kasuks ja märgivad, et meditsiinitöötajad peaksid teadma patsiendi usulisi veendumusi. Eesti tervishoiusüsteemil on huvi ja vajadus nii spetsialistide täiendõppe/väljaõppe järele, kui ka üldise informatsiooni järgi, mis puudutab religioosseid, spirituaalseid teemasid tervishoius (Meel \& Linnuste \& Uibu 2016).

Spirituaalse dimensiooni lisamine tervisekontseptsiooni annab aluse käsitleda spirituaalsust indiviidi sisemise ressursina, mis aitab uues olukorras tähenduse, mõtte ja eesmärgi leidmisel. Patsientide vaimsete vajaduste hindamiseks ja kaardistamiseks on loodud mitmeid skaalasid ja teste ${ }^{7}$ ning antud soovitusi (Fitchett 2003), kuidas integreerida antud temaatikat psühhoteraapiasse (Pargament 2007). Samuti saab paralleele tuua positiivse psühholoogiaga, mille puhul keskendutakse psühhopatoloogia asemel elujaatavate väärtuste ja tugevuste kaardistamisele, nagu õnn, armastus ja elulised väärtused. ${ }^{8}$ Kuue iseloomuliku tugevuse ehk vooruse alt leiame tarkuse/teadmise, julguse, inimlikkuse, õigluse, mõõdukuse ja transtsendentsuse. Transtsendentsus on võime suhteks või suhtlemiseks universumiga ja võime leida oma ellu tähendus. Inimese elu, tema tunnete kogemuse tähendus ei peitu inimeses endas, vaid milleski kõrgemas kui inimene ise. Transtsendentsuse kui vooruse alla mahuvad viis loomutugevust, millest üks on ka spetsiifiliselt spirituaalsus ning usklikkus (inimesel on väljakujunenud seisukohtade süsteem, mis omab tähendust elu ja universumi kohta ja kogu elu asetamine laiemasse perspektiivi) (Lehtsaar 2013: 202-208).

Patsientide spirituaalsusega seotud aspektid, nagu tähendus, eesmärk, kooskõla, terviklikkuse tunne, universaalsed väärtused jt, on tema seisundi tervikpildi mõistmisel olulised (Culliford 2002), ning seda on tunnustanud ka Maailma Terviseorganisatsioon ${ }^{9}$ (WHO). 


\section{Diagnostilised kriteeriumid}

Tulenevalt kirjeldatud religioossest lõhest ning üldisest teema tundlikkusest on võimalik, et psühhiaatrilisele ravile või psühholoogi vastuvõtule sattunud patsient kardab oma kriisiga seonduvaid R/S vajadusi või põhjuseid ravipersonalile avada. Seetõttu võib psühhiaatriline diagnoos olla ebatäpne või üldistav (depressioon, psühhootiline häire jm) ja ravi ning terapeutiline sekkumine ei kanna vilja. Teisest küljest ongi raske leida täpset ja õiget diagnoosi või diferentsiaaldiagnoose. Psühhiaatrias võidakse tõlgendada psühhootiliseks mitmeid vaimseid avanemisi ja hädaolukordi (spiritual emergence and emergency), nagu Stanislav ja Christina Grof neid kutsuvad (Grof 2008b: 184-191), ja eksistentsiaalsetes kriisides, logoteraapilise terminina noogeense neuroosina (Frankl 2001: 162-163) näha pelgalt depressiooni ilminguid. ${ }^{10}$ Piir spirituaalse kriisi ja psühhootilise seisundi vahel ongi sageli väga õrn. Näiteks kasvõi karismaatilistes usukogudustes ekstaatiline glossolaalia ("keelte rääkimine"), ${ }^{11}$ millesse usuvad paljud kristlased, eriti nelipühilased, samuti jumala hääle valjult kuulmine või muu nn vaimuandidega seonduv. Nende fenomenide uurimisele on pühendunud psühhiaater Simon Dein. Tema uuringust tuleb esile, et 40 Inglise nelipüha kiriku liikmest, kelle palvetamisi uuriti, teatasid 25, et saavad jumalalt vastuseid ning 15 vastanutest väitis kuulvat jumala häält valjusti nendega kõnelemas (Dein \& Littlewood 2007). Tuleb lisada, et kõik uuritavad olid eluga hästi toimetulevad inimesed, kellel puudusid seosed vaimse tervise probleemidega. Religioosses kontekstis on uuritud häälte kuulmist nii psühhootilisest kui ka spirituaalsest lähtekohast ning tõdetud, et spirituaalsus võib aidata kaasa häälte põhjustatud düstressiga toimetulekul (McCarthy-Jones \& Waegeli \& Watkins 2013).

Esimene samm arvestamaks spetsiifilisemalt religioosseid ja spirituaalseid probleeme psühhiaatrias on Ameerika Psühhiaatrite Assotsiatsiooni vaimsete häirete diagnostilise ja statistilise käsiraamatu (DSM) IV väljaandes teemakohase V koodi kasutuselevõtmine, kuhu kuulub ka alavaldkond religioossed või spirituaalsed probleemid (Religious or spiritual problems V62.89) (DSM IV 2000).

Et mitte takerduda diagnooside koodide raamistikku parafraseerin Saksa teoloogi ja meditsiinieetiku Ulrich Körtneri mõtet spirituaalsusest tervishoiusüsteemis: ei tohi ära unustada, et ravimine on kunst - arstikunst, millele vastandub meditsiini muutumine mehaaniliseks süsteemiks (Körtner 2016). Vaimsel tasandil pole tähendust sellistel raamidel ja tiitlitel nagu arst, patsient, õde, psühholoog, kaplan. Need on vaid formaalsed tähistajad. Seega on väga oluline aktsepteerida spirituaalset, parareaalset kogemust ja töötada patsiendi, mitte siltidega. Teha vahet spirituaalsel psühhopatoloogial ja spirituaalsel 
kriisil ehk ressursil, millega on võimalik terapeutilises suhtes töötada. Terapeudi personaalne spirituaalsus aitab tal sageli märgata ka patsiendi spirituaalseid vajadusi. Spirituaalse intelligentsi arendamine on siinjuures väga oluline (Baldacchino 2015). Ameerika psühhiaatri James Lake'i arvates peaks arst patsiendile selgitama, et teda huvitab patsient tervikuna, mitte ainult psühhiaatriline diagnoos. Selline lähenemine tugevdab arsti-patsiendi suhet ning see võib tulla kasuks ravist kinnipidamisele ja lõpptulemustele. Lõhe psühhiaatria ja religiooni vahel võib vähemalt osaliselt olla vastus psühhiaatria progressile vaimsete haiguste bioloogiliste ja füsioloogiliste põhjuste väljaselgitamisel, kui religioosseid põhjuseid peetakse ebaolulisteks (Lake 2012). 2017. aastal avaldatud väljaandes "Spirituaalne hoolekanne ja arstid: Mõistmaks spirituaalsust meditsiinipraktikas" on välja toodud peamised põhjused, miks ei pakuta R/S teemakohast toetust patsientidele ja peredele. Kuigi uuringuid on vähe, on barjäärid siiski silmatorkavad. Nagu selgub, on üheks peamiseks teguriks ajanappus. Teine põhjus: puudub piisav väljaõpe. Kolmandana on välja toodud ebamugavustunne R/S teemade käsitlemisel patsiendiga, aga on ka tõdetud, et ei olegi arsti roll nendel teemadel vestelda. Arstid on ise välja toonud ka võimuvahekorra, mis paneb patsiendi nendel teemadel vesteldes ebamugavasse positsiooni. Üldjoontes on R/S teemasid käsitlevad arstid ka ise religioossed või spirituaalsed ning enamik arste tunneb teemade käsitlemisel ennast mugavalt, kui patsient ise toob teemad vestluses esile (Marin \& Sharma et al. 2017).

Tabelisse 1 on koondatud erinevaid spirituaalseid ja religioosseid kriise, mis on kombineeritud ja kohandatud valdavalt David Lukoffi ja tema kolleegide töödes väljatoodud kriisidest (Lukoff \& Lu et al. 2011: 21-50, 180).

Tabel 1. Spirituaalseid ja religioosseid kriise

\begin{tabular}{|l|}
\hline Religioosne probleem \\
\hline Usulahu muutused (denominatsioon/conversion) \\
\hline Konversiooni "pöördumise kogemused" \\
\hline Religioossete praktikate ja usu tugevnemine (intensiivsus) \\
\hline Usukaotus \\
\hline $\begin{array}{l}\text { Ühinemine "uue religioosse liikumise" või kultusega või lahkumine } \\
\text { sellest (New Religious Movement) }\end{array}$ \\
\hline Muu religioosne probleem \\
\hline Spirituaalne probleem \\
\hline Usu kaotus \\
\hline Surmalähedased kogemused (NDE, near death experiences) \\
\hline Kehast väljumise kogemused (OBE, out of body experiences) \\
\hline $\begin{array}{l}\text { Müstilised kogemused (epifaaniad, peak-experiences, cosmic } \\
\text { consciousness jne) }\end{array}$ \\
\hline
\end{tabular}




\begin{tabular}{|l|}
\hline Tulnukatekontaktid (AAE, alien abduction experiences) \\
\hline Kundalini psühhoos, Kundalini “ärkamine” \\
\hline Šamaanikriis \\
\hline Psüühiline avanemine \\
\hline Eelmiste elude mäletamine \\
\hline Seestumus \\
\hline $\begin{array}{l}\text { Erinevate meditatsioonitehnikate või spirituaalsete praktikatega } \\
\text { seotud kogemused }\end{array}$ \\
\hline Eraldumine vaimsest õpetajast \\
\hline
\end{tabular}

\section{Arutelu: religioosne ja spirituaalne probleem}

Ja ma pühendasin oma südame tarkuse mõistmisele, ka meeletuse ja sõgeduse mõistmisele: ma mõistsin, et ka see oli vaimunärimine. Sest kus on palju tarkust, seal on palju meelehärmi, ja kes lisab teadmisi, see lisab valu. (Koguja 1: 17-18)

Võttes arvesse spirituaalsete kriiside dünaamikat ning avaldumise vorme, saan välja tuua kaks peamist kategooriat: a) otsingutega ja vajadustega (terviklikkuse, kannatuse mõtestatuse, ühtsuse, Jumala otsingud) seonduvad teemad, mida saab seostada neuroosiga, ning b) spontaanselt esilekerkivad (müstilised kogemused, epifaaniad, nägemused, ekstrasensoorsed kogemused jm) teemad, mida vaimse tervise kontekstis saab seostada psühhootiliste episoodidega, sest sageli kaasnevad nendega muutused teadvuse seisundites. Teadvuse muutunud seisundid on spirituaalsete kriiside korral küllaltki sagedased. Enamjaolt on need tingitud viiest põhjusest, tabel 2. (Vaitl \& Birbaumer et al. 2005). Seoses mitmete spirituaalsete praktikatega kutsutakse neid esile ka tahtlikult.

Tabel 2. Teadvuse muutustega seotud valdkonnad klassifitseeritud nende päritolu või induktsioon meetodi alusel

\begin{tabular}{|l|l|}
\hline Spontaanselt avalduvad & $\begin{array}{l}\text { surmalähedased kogemused; hüpnagoogsed } \\
\text { seisundid, unenäod jne }\end{array}$ \\
\hline Füüsilised ja füsioloogilised & $\begin{array}{l}\text { äärmuslikud keskkondlikud tingimused; } \\
\text { nälg, dieet ja paastumine, seksuaaltehnikad, } \\
\text { hingamistehnikad }\end{array}$ \\
\hline Psühholoogilised & $\begin{array}{l}\text { sensoorne deprivatsioon, muusika, hüpnoos, } \\
\text { meditatsioon, trummid, rütmid, tantsimine, } \\
\text { biotagasiside }\end{array}$ \\
\hline Patoloogilised & $\begin{array}{l}\text { epilepsia, ajukahjustus, psühhootilised } \\
\text { seisundid, kooma ja vegetatiivsed seisundid }\end{array}$ \\
\hline Farmakoloogilised & psühhoaktiivsed ja psühhedeelsed ained \\
\hline
\end{tabular}


Kriiside eest ei ole kaitstud ka vaimulikud. Arndt Büssing ja tema kolleegid uurisid Saksamaal spirituaalseid kriise katoliku preestrite hulgas (valim oli 3824 preestrit). Uuringust ilmnes, et ainult 6\% ei esinenud üldse kriisi sümptomeid; aeg-ajalt esines $46 \%$, ning sageli või regulaarselt $12 \%$, samas $36 \%$ koges seda harva (Büssing \& Günther et al. 2013).

Spirituaalne kriis (spiritual dryness) on seotud psühhosomaatilise düstressiga, üksildusega ja väheste sisemiste ressursside olemasoluga. Enim eeldusi selleks andsid vähene transtsendentsi tajumine, vähene tunnetatud sidusus (koherentsuse tunne) ${ }^{12}$, depressiooni ja läbipõlemise sümptomid (joonis 2).

NÕUDMISED

\begin{tabular}{|c|c|c|}
\hline $\begin{array}{l}\text { Välised } \\
\text { Tajutud stress } \\
\text { Üksildus }\end{array}$ & & $\begin{array}{l}\text { Välised } \\
\text { Sotsiaalne toetus }\end{array}$ \\
\hline & $\begin{array}{l}\text { Spirituaalne kriis } \\
\text { (spiritual dryness) }\end{array}$ & \\
\hline $\begin{array}{l}\text { Sisemised } \\
\text { Depressioon/ärevus } \\
\text { Läbipõlemine }\end{array}$ & & $\begin{array}{l}\text { Sisemised } \\
\text { Transtsendentsi tajumine } \\
\text { Tunnetatud sidusus } \\
\text { Enesetõhusus }\end{array}$ \\
\hline
\end{tabular}

Joonis 2. Spirituaalne kriis ja düstress.

Uuringust järeldub, et ka preestrid võivad tunda spirituaalseid kriise, mida saab siduda depressiooni sümptomitega. Spirituaalsete kriisidega toimetulek võib anda vaimse kasvu, kui kriisiga ei tegeleta ja kriisi arengut vaimse kasvu poole ei toetata, võib see viia veel sügavamale meeleheitesse, seega on väga oluline mõista ja toetada pastoraalse töö tegijaid ning laiendatult kõiki inimestega töötavaid spetsialiste. Psühholoogide seas on oluline koht nii eneseteraapial kui ka supervisioonil. ${ }^{13}$

Üldistavalt võiks väita, et religioossele inimesele või ka usukogudusega alles liituvale indiviidile mõeldes eeldatakse sageli, et jumalaga nii-öelda käsikäes või sinasõpruses oleval isikul on kõik vajadused, kohustused, eetika ja moraal, voorused ja väärtused selgepiirilised, piiblist lähtuvad ning elu igati harmooniline. Ometi on usklikudki inimesed seotud maiste ihade, murede ja 
väljakutsetega ehk füsioloogilis-bioloogiliste isenditena allumas psühholoogilisele stressile ja diateesi mudelile ${ }^{14}$ ning sealt on vahel vaid sammuke psüühikahäireteni. Seega vahel värske usukoguduse initsieeritud (näiteks ristitud) liikmena väljakutsed alles algavad. Romantiliselt võib seda nimetada saatana poolt proovile panekuks, kuid psühholoogiliselt on tegemist spirituaalse kriisiga, või tulles usklike inimeste väljakutseid uuriva Julie Exline'i väite juurde, vaimse heitlusega (spiritual struggles). Läbi kahtluste, süütunde, häbitunde võib kogu uskliku inimese spirituaalne kriis kulmineeruda jumala vihkamises ja blasfeemias. Exline (Exline \& Rose 2005) jagab spirituaalsed/religioossed kriisid nelja rühma:

1. Süütunded jumala ees. Kannatuste väljakutse. Kõiki inimesi on puudutanud mingisugune tõsisem kannatus. Olgu selleks armastatud inimese surm, kodu hävimine õnnetusjuhtumi vms tagajärjel, rääkimata kuritegude ohvriks langemisest või rasketest haigustest. Seistes silmitsi kannatustega, hakkab inimene omistama juhtunule põhjuseid ja otsima vastutajat, kelleks sageli osutub jumal. Kerkib viha jumala vastu.

2. Voorustega seotud väljakutsed. Patt, ohverdused, enesele andestamine. Enamik religioone on seotud kindlate reeglite järgmisega, pattude vältimise ja vooruste kasvatamisega. Religioon tundub paljudele negatiivsena, sisaldades institutsioonide poolt pealesunnitud rituaale ja norme. Võimalik, et see punkt on juhtinud paljusid just tänapäevase individualistliku spirituaalsuse juurde, isiklike uskumussüsteemide ja eetika ning voorustega.

3. Vaimne maailm rünnakute all. Kurjuse väljakutse. Kui esimene punkt asetas fookusse autoriteetse jumal-karistaja, siis siin on rünnakud seotud saatana, deemonite ja kurjade jõududega (diabolical causation). Siia alla kuuluvad ka nn seestumisega (possession) seotud juhtumid. Paljud inimesed usuvad, et saatanlikud jõud on endiselt meie moodsas maailmas tegevuses, omistades neile kannatuste ja hädade põhjused.

4. Üleloomulikust kannatusest tagasi loomulikku kannatusse (from the Supernatural to the All-Too-Natural). Religioosse kogukonnaga seotud väljakutsed. Religioossed probleemid taanduvad sageli ilmalikele põhjustele ning on seotud eelkõige inimestevahelise suhtlemise ja läbisaamisega. Nii nagu solvutakse ja saadakse haiget igapäevaelus, juhtub see ka religioosses kogukonnas, kogudustes. Mõned juhtumid on eriti traagilised, seotud seksuaalse ärakasutamise, finantsmahhinatsioonide ja korruptsiooniga religioossete autoriteetide poolt. Religioossed kogukonnad ei ole immuunsed kuulujuttudele, ahnusele, võimuvõitlusele, armukadedusele jne. Religioossete liidrite silmakirjalik käitumine peegeldub kogu religioonis ning paljud üksikisikud ei taha ennast siduda saastunud süsteemiga. 
Enamjaolt ei oska inimesed isegi eristada negatiivseid ja positiivseid tundeid jumala suhtes, seda enam, et ambivalentsena võivad need koos esineda ja esinevadki. Viha jumala vastu ei tähenda veel jumalasuhte katkemist. Valehäbis emotsioone varjates ja neid alla surudes võivad pinged pigem lumepalliefektina varem või hiljem välja plahvatada või võtta patoloogilise kulu. Oma tundeid teistega jagades ootavad või eeldavad inimesed sageli toetust ja julgustust. Exline lisab, et kui inimene tunneb jumala suhtes tabuks peetud negatiivseid tundeid ja üritab neid jagada teiste inimeste või jumalaga, on oluline kõrvalnähtus hirm tunnistada neid tundeid iseendalegi. Käitutakse küll korrektselt, palvetatakse jne, kuid lähedus, intiimsus on blokeeritud. "Elevant on toas" nii-öelda. (Exline 2014)

R/S teemade põhjustatud düstress, mil patsientide uskumuste ja veendumuste süsteem ei suuda enam pakkuda lahendust eksistentsiaalses ängis, vajab spetsiifilist sekkumist ja toetust. Kui personaalsed uskumussüsteemid on vastuolus (notseebo efekt) tervenemise dünaamikaga, annab see tagasilöögi kogu paranemise dünaamikale (Saad \& de Medeiros 2012). Soovituslik oleks siinkohal eksistentsiaalne psühhoteraapia ${ }^{15}$, mis toob tähenduse ja elu eesmärgi leidmise patsiendiga tegelemisel esiplaanile (Spinelli 2006).

Kui aidata abivajajal eelnevalt käsitletud düstressi teadlikult ja oskuslikult teadvustada, võib seni regressioonina näivast psühhopatoloogiasse kalduvast vaakumist saada tõuge vaimseks ärkamiseks ning isiksuse transformatsiooniks taastumise teekonnal.

Tänane psühhiaatria ei erista veel spirituaalseid kriise, müstilisi kogemusi ja kontakte psühhootilistest seisunditest. Stanislav Grofi peamine kriitika spirituaalsete kriiside teadvustamise valdkonnas on seotud sellega, et mitmed psühhootilised episoodid võivad olla spirituaalsed kriisid, kus toimub isiksuse transformatsioon ja areng vaimse avanemise suunas. Kui need episoodid farmakoloogilise raviga nii-öelda maha võtta ning mitte sekkuda ka spetsiifiliselt psühhoteraapiliselt, jääb areng toppama ja katkeb arengu potentsiaal. Seetõttu on Christina ja Stanislav Grof kasutanud spirituaalsetest kriisidest rääkides sõnademängu emergency ehk hädaolukord, erakorraliselt või äkitselt esile kerkinud, ning emergence, esiletulek, mis viitab tekkimisele või esiletõusule, kus probleemile on sisemiselt omane ka võimalus, lahendus (Grof 2008b).

Spirituaalsete hädaolukordade olemasolu tunnistamine ei tähenda seda, et me hülgame peavoolu psühhiaatria teooriad ja meetodid. Mõned tavatud seisundid on oma olemuselt selgelt bioloogilised ja nõuavad meditsiinilist farmakoloogilist ravi. Peavoolu psühhiaatritel on kalduvus müstilisi seisundeid patologiseerida, tõdeb Stanislav Grof, kuid samas on olemas ka vastupidine eksimus, mille puhul psühhootilisi seisundeid romantiseeritakse ja ülistatakse ning vaadatakse mööda tõsisest meditsiinilisest probleemist (Winter 2009). 
Kui spirituaalne areng on järk-järguline ja leiab aset kontekstis, mis võib toetada isiklikke muutusi maailmapildis, ei tohiks esineda mingit üleminekukriisi. "Kui spirituaalse kogemuse esiletulek on väga järsk ja traumaatiline, võib see loomulik protsess muutuda kriisiks ja spirituaalsuse avaldumisest saab pigem spirituaalne hädaolukord" (Randal \& Argyle 2005).

Viimastel aastakümnetel oleme olnud tunnistajaks kasvavale huvile vaimsete teemade vastu, millega on kaasnenud laialdane eksperimenteerimine iidsete, pärismaiste kommetega ja tänapäevaste "pühaduse tehnoloogiatega" - meeleseisundeid muutvate tehnikatega, mis võivad viia vaimsete avanemisteni, kuid ühtlasi on sellega kaasnenud spirituaalsete kriiside ja hädaolukordade sagenemine (Grof 2008b).

\section{Kriitika spirituaalse või religioosse sisuga toetuse suhtes ning kriitika mõju abivajajale}

Kahe kliinilise katse (viidi läbi sõltuvusravi statsionaarsete patsientide seas) tulemused (Miller \& Forcehimes et al. 2008) viitavad sellele, et spirituaalsuse kaasamine ravisse liiga vara ei avalda patsientidele olulist mõju. Spirituaalne areng on kogu elu kestev protsess, seega ei pruugi inimene mõne häire akuutses faasis suuta haarata nn suuremat pilti. Ameerika psühholoogi Abraham Harold Maslow' teooria järgi täidavad inimesed oma vajadusi enamasti kindlas hierarhilises järjekorras: ellujäämine, turvalisus, armastus ja kuulumine, enesehinnang, eneseteostus ja kõige viimasena spirituaalsed ehk transtsendentsed vajadused (Maslow 1964). Võib-olla on varajases ravistaadiumis inimestele teised vajadused lihtsalt suurema tähtsusega kui spirituaalsed. Sellisel juhul ei ole spirituaalsuse õhutamine sel hetkel õigesti ajastatud. Seega peab patsiendile lähenema küll patsiendikeskselt, kuid arvestama tema enda nii-öelda spirituaalset intelligentsust.

Kuigi enamik uurimusi on näidanud positiivseid mõjusid, võivad religioon ja spirituaalsus tervist mõjutada ka negatiivselt. Kindla religioosse eluviisiga inimestel, samuti erinevate spirituaalsete suundumuste ja hoiakutega seotud inimeste ravikoostöös võib esineda ohtralt konflikte, millega peavad arvestama nii arst, terapeut kui ka abivajaja. Konfliktid võivad kerkida nii koguduste kui üksikisikute pinnalt. Bruce Y. Lee ja Andrew B. Newberg (2005) toovad oma artiklis välja mitmed uuringud, mille kohaselt usurühmad võivad olla teatud tervishoiumeetmete (nt vereülekanne või rasestumisvastased vahendid) otsesed vastased ning veenda patsiente, et nende hädad tulenevad mitteallumisest usudoktriinidele, mitte orgaanilisest haigusest. Lisaks võib religioon teatud haigustega inimesi stigmatiseerida nii, et nad ei otsigi asjakohast meditsiinilist 
abi. Samuti ei saa mööda vaadata maailmas toimuvatest usulistest konfliktidest ja nende ohvritest, usujuhid võivad enda järgijaid väärkohelda nii füüsiliselt, emotsionaalselt kui ka seksuaalselt. Kui haigust põhjustab segu religioossetest, spirituaalsetest ja orgaanilistest põhjustest, võib haiguse üldine ravi muutuda väga keeruliseks.

Psühhootilisi seisundeid või veidrat käitumist, mis võib olla skisofreeniat ennustav prodromaalsümptomaatika, ei tohi romantiseerida ja vaadata mööda tõsisest meditsiinilisest probleemist. Oluline on konsulteerida nii psühhiaatritega kui ka väljaõppinud spirituaalset toetust pakkuvate spetsialistidega, sest (parafraseerides Ameerika õpetlast Joseph Campbelli:) sinna, kus müstik suudab ujuda, psühhootiline inimene upub.

\section{Kokkuvõte}

Inimene on lisaks bioloogilisele kehale ning psühholoogilistele ja sotsiaalsetele aspektidele spirituaalne olend. Maailmas on palju sellist, mida me ei suuda veel selgitada, kuid millele inimkogemus siiski reageerib kas positiivselt või negatiivselt. Artikkel käsitles spirituaalsusega kaasnevaid võimalikke varjukülgi ehk spirituaalsete kogemuste negatiivseid tõlgendusi, mis avalduvad erinevates kriisides. Spirituaalseid kriise saab mitmeti vaadelda ning omakorda osadeks jaotatuna esile tuua aspekte, mis haakuvad inimese vaimsete vajadustega. On ka kriise, mis haaravad inimese spontaanselt ning võivad seetõttu mõjuda halvavalt kogu edasisele elule. Et pakkuda inimese mitmemõõtmelisse spektrisse ulatuvatele kogemustele vastavat abi, on tervishoius oluline arvestada spirituaalsete kriisidega, arendada diagnoosimist ja vajadusel kaasata diferentsiaaldiagnoose. Nagu eelnevalt kirjeldatud, peidavad mitmed neist häid võimalusi isiksuse arenguks ning seega kätkevad endas varjatud kujul pigem ravipotentsiaali ja positiivset dünaamikat kui psühhopatoloogiat. Samas oleks väljapoole tervishoidu jäävatel inimestel vaja teadvustada spirituaalsete kogemustega kaasas käivaid varjukülgi kuni patoloogiliste ilminguteni. On suur oht mitmeid kogemusi romantiseerida ning jätta seetõttu inimene abi või ravita. Psüühikahäirete avaldumise eest ei ole kahjuks kaitstud ka vaimulikud ja spirituaalsete praktikatega tegelevad inimesed. Kasvav huvi erinevate uue vaimsuse valdkonda jäävate praktikate vastu, kus on segunenud ühelt poolt kiirete vaimsete kogemuste ja lahenduste otsing ning teisalt mitmed kultuuri- ja religiooniruumid, toovad spirituaalsuse varjuküljed suhteliselt kiiresti vaimse tervise spetsialistide tööpõllule. Spirituaalsed vajadused on inimesele omased ning sageli kerkivad need esile just haiglavoodis. On mitmeid meetodeid, kuidas koguda infot patsiendi vajaduste kohta, vahel piisab anamneesi käigus esitatud 
lihtsatest küsimustest, mis annavad spetsialistile vajalikud teadmised, mida arvestada raviplaani koostamisel. Tervishoiutöötajatel on küll huvi, kuid sageli jääb väheks ajast ning nad vajaksid lisateadmisi R/S spetsiifikast. Nii mõnegi haiguse või häire käsitlemisel võib vaatenurga muutus anda sootuks teise arusaamise selle põhjustest. Kahjuks ei ole Eestis eksistentsiaalse suunitlusega psühhoteraapia suunad hästi integreerunud psühhiaatrias, samuti puudub süsteemne hingehoiu, spirituaalse toe või haiglakaplanite integreeritus ravimeeskondadesse. Eesti Haigekassal puudub tasuliste teenuste hinnakirjast ka hingehoiu teenus. Tervishoiusüsteemil on mitmeid väljakutseid parendamaks tervishoiuteenuste mitmekesisust selles valdkonnas. On soovitatav koolitada tervishoiutöötajaid religioossete ja spirituaalsete teemade osas.

\section{Allikad}

Meel, Liidia \& Linnuste, Indrek \& Uibu, Marko 2016. Tervisevaldkonna spetsialistide arvamused ning kogemused spirituaalsuse, hingehoiu ja meditsiinilise pluralismi teemadel. Arvamused ja kogemuslood on hoiul Tartu Ülikooli usuteaduskonnas.

\section{Kommentaarid}

1 Eesti kuulub suurima enesetapuriskiga maade hulka; 1994. aastal võttis endalt elu 614 inimest (European Health for All database (HFA-DB) http://www.euro.who.int/en/ data-and-evidence/databases/european-health-for-all-database-hfa-db - 4. november 2019).

2 Eesti elanike alkohoolsete jookide tarbimine arvestatuna $100 \%$ alkoholis oli 2013. aastal 10 l elaniku kohta. Maailma Terviseorganisatsiooni (WHO) hinnangul toob juba üle 61 puhta alkoholi tarbimine elaniku kohta aastas kaasa tõsise kahju rahva tervisele. Tervise Arengu Instituudil on olemas ka vastava sisuga veebilehekülg: http://alkoinfo. ee/et/faktid/alkoholitarbimine-eestis (vaadatud 06.11.2019).

3 Uus vaimsus on religioonisotsioloogias kasutusele võetud termin, et tähistada teatud subkultuuri ning keskkonda, mis seob endas erinevaid eklektilisi tehnikaid ja õpetusi, mis varasemalt oli paljus seonduv mõistega new age (Altnurme 2013).

4 Artikli fookuses on religioossed ja spirituaalsed kriisid (R/S) valdavalt koos, välditud on diskussiooni nende mõistete erinevuste üle. Usulised ja vaimsed väljendusviisid võivad olla väga laialdased, kattuvad ja mitmekesised. Religioosse kriisi all mõistetakse enim seost kindla institutsionaliseeritud religiooni või usulise doktriiniga ja veendumusega. Spirituaalsust on käsitletud laiemana kui väljatoodud definitsioonis, see võib olla aga ei pruugi olla seotud kindla religiooniga. Kriisid konkreetsemalt on välja toodud tabelis 1 .

5 Erialases kirjanduses ja erinevates teemakohastes materjalides on spirituaalse kriisi iseloomustamiseks kasutatud erinevaid oskussõnu: problems, emergency, distress, struggles, conflicts, dryness, crisis jne. Siinses artiklis üldistan ja koondan toodud 
mõisted ühiselt spirituaalse kriisi mõiste alla, sest artikli eesmärk on tuua fookusesse teema käsitlemine laiemalt, mitte rõhutada spetsiifilisi mõisteid kitsamalt.

6 Antud uuringus võrreldi Ameerika elanike arvamusi 1998. aastal läbiviidud küsitluse alusel (The General Social Surveys (GSS)), kuhu oli lisatud ka Fetzeri Instituudi poolt väljatöötatud lühike mitme mõõtmeline religioossuse/spirituaalsuse küsimustik (www. fetzer.org - 07.09.2019).

7 Näiteks Christina Puchalski arendatud FICA meetod, vt Puchalski \& Romer 2000.

8 Martin Seligman ja tema kolleegid, kes tõid psühholoogiasse positiivse psühholoogia suuna, koostasid positiivse vaste "Diagnostilisele ja statistilisele psüühikahäirete käsiraamatule" (Diagnostic and Statistical Manual of Mental Disorders, DSM). Kui DSM keskendub sellele, mis võib minna valesti ehk patoloogiale, on nende raamat "Iseloomu tugevused ja voorused" (Character Strengths and Virtues) loodud vaatama seda, mis teeb inimesed õnnelikuks ning tugevdab nende vaimu ja toimetulekut (Seligman \& Peterson 2004).

9 Ajalooliselt kulmineerus Maailma Terviseorganisatsiooni kontseptsioonis spirituaalsete väärtuste nii-öelda lauale toomine 1983. aasta assambleega ning ühise avaldusega, et spirituaalsel dimensioonil on oluline tähtsus rahvatervisele, seda tuleb rakendada tervishoius. WHO mõistab spirituaalset tahku elukvaliteedi kontseptsioonis, kui aspekti, mis isiklike uskumuste kaudu mõjutab indiviidi elukvaliteeti. (http:// apps.who.int/iris/bitstream/handle/10665/159897/WHA36_A-Conf.Paper-9_eng. pdf?sequence $=1-07.11 .2019$ ).

${ }^{10}$ Noogeense neuroosi aluseks on konflikt erinevate väärtuse vahel, eetiline konflikt või vaimne probleem. Eksistentsiaalne frustratsioon pole iseenesest patoloogiline ega patogeenne, kui kantus on suunatud arengu, kriisi lahendamise teenistusse (http:// www.tlu.ee/ arno/frankl_moskvas.pdf - 07.11.2019).

11 1. Kr. 12 Vaimuandidest ja 1 . Kr. 14 keelte rääkimisest ja prohvetlikult kõnelemisest; Ap 19:6: "Ja kui Paulus pani oma käed nende peale, tuli neile Püha Vaim ja nad rääkisid võõraid keeli ja ennustasid.”

12 Tunnetatud sidusus on Aaron Antonovsky esitatud salutogeneetilise tervisekäsitluse keskne mõiste, mis tähistab üldist vastupanuressurssi, isiksuslikku eelsoodumust kogeda sündmusi mõistetavate, juhitavate ja mõtestatutena (Rüütel 2003).

${ }^{13}$ Supervisioon on süstemaatiline nõustamisprotsess, mis on vajalik eelkõige inimestega töötavatele professionaalidele ja nende tööks ning võib toimuda vastavalt vajadusele erinevates vormides ja vahenditega. Supervisiooni kasutamine annab häid tulemusi paljude tegevusvaldkondade, kuid eelkõige sotsiaaltöö-, haridus-, täiskasvanuharidus-, personalitöö-, tervishoiu-, psühhoteraapia-, hoolekandevaldkonnas töötavate inimeste puhul (vt http://supervisioon.ee/supervisioonist/ - 11.11.2019).

${ }^{14}$ Diateesi-stressi mudeli kohaselt on psüühikahäire tekkimiseks vaja kahte tegurit: ühte, mis kujundab häire tekkimise riski, ja teist, mis aktiveerib riski.

${ }^{15}$ Eksistentsiaalse psühhoteraapia all mõtlen üldistatult Victor E. Frankli, Irwin Yalomi, Rollo May, Roberto Assagioli (1993) jt humanistliku ja eksistentsialistliku psühholoogia sekkumisi, mis keskenduvad inimeksistentsi alusstruktuuridele ega tegele n-ö akuutsete olukordadega, käitumise ja kognitiivsete protsessidega. 


\section{Kirjandus}

Altnurme, Lea 2013. Uus vaimsus - mis see on? Uibu, Marko (toim). Mitut usku Eesti III: Uue vaimsuse eri. Tartu: Tartu Ülikooli kirjastus, lk 18-36 (https://www.tyk.ee/ admin/upload/files/raamatud/1388589914.pdf - 12. november 2019).

Assagioli, Roberto 1993. Transpersonal Development: The Dimension Beyond Psychosynthesis. London: Aquarian/Thorsons.

Baldacchino, Donia 2015. Spiritual Care Education of Health Care Professionals. Religions 6 (2), lk 594-613 (doi: 10.3390/rel6020594).

Banin, Luciana Burgugi \& Suzart, Nadielle Brandani \& Guimarães, Fernando Augusto Garcia \& Lucchetti, Alessandra Lamas Granero \& de Jesus, Marcos Antonio \& Lucchetti, Giancarlo 2014. Religious beliefs or physicians' behavior: what makes a patient more prone to accept a physician to address his/her spiritual issues? Journal of Religion and Health 53 (3), lk 917-928 (doi: 10.1007/s10943-013-9685-2).

Büssing, Arndt \& Günther, Andreas \& Baumann, Klaus \& Frick, Eckhard \& Jacobs, Christoph 2013. Spiritual dryness as a measure of a specific spiritual crisis in catholic priests: associations with symptoms of burnout and distress. Evidence-Based Complementary and Alternative Medicine (doi: 10.1155/2013/246797).

Büssing, Arndt \& Koenig, Harold G. 2010. Spiritual Needs of Patients with Chronic Diseases. Religions 1, lk 18-27 (doi: 10.3390/rel1010018).

Catechism of the Catholic Church 1993. Citta del Vaticano: Libreria Editrice Vaticana (http:// www.vatican.va/archive/ccc_css/archive/catechism/p4s1c3a2.htm - 28. september 2018).

Cook, Chris H. 2004. Addiction and spirituality. Addiction 99, lk 539-551 (doi: 10.1111/j.1360-0443.2004.00715.x).

Cook, Chris H. \& Powell, Andrew \& Sims, Andrew (toim) 2009. Spirituality and Psychiatry. London: Royal College of Psychiatrists Press 4.

Culliford, Larry 2002. Spiritual care and psychiatric treatment: an introduction. Advances in Psychiatric Treatment 8 (4), July, lk 249-258 (doi: 10.1192/apt.8.4.249).

Curlin, Farr A. \& Lantos, John D. \& Roach, Chad J. \& Sellergren, Sarah A. \& Chin, Marshall H. 2005. Religious characteristics of U.S. physicians: A national survey. Journal of General Internal Medicine 20 (7), lk 629-634 (doi: 10.1111/j.1525-1497.2005.0119.x).

Curlin, Farr A. \& Chin, Marshall H. \& Sellergren, Sarah A. \& Roach, Chad J. \& Lantos, John D. 2006. The association of physicians' religious characteristics with their attitudes and self-reported behaviors regarding religion and spirituality in the clinical encounter. Medical Care 44 (5), lk 446-453 (https://pdfs.semanticscholar.org/edbf/168200b514527 2ef9a3dbc1e96fcb86cd7f0.pdf - 26. november 2019).

Dein, Simon 2009. The Faith of Patients. Presentation given at the Annual Meeting of the Royal College of Psychiatrists, Liverpool, June (https://www.rcpsych.ac.uk/pdf/ Dein\%20The\%20Faith\%20of\%20Patients.x.pdf - 28. september 2018, see lehekülg ei ole enam kättesaadav).

Dein, Simon \& Littlewood, Roland 2007. The Voice Of God. Anthropology and Medicine 14 (2), lk 213-228 (doi: 10.1080/13648470701381515). 
DSM IV 2000. Diagnostic and Statistical Manual of Mental Disorders, 4th ed. Text Revision. Arlington: American Psychiatric Publishing.

Durà-Vilà, Gloria \& Dein, Simon 2009. The Dark Night of the Soul: spiritual distress and its psychiatric implications. Mental Health Religion \& Culture, lk 1-17 (doi: 10.1080/13674670902858800).

Eesti-Rootsi vaimse tervise ja suitsidoloogia instituut 2008. Enesetappude ennetamine: abiks esmatasandi tervishoiutöötajatele. WHO väljaande Eestile kohandatud ja täiendatud tõlge. Tallinn: Eesti-Rootsi vaimse tervise ja suitsidoloogia instituut (https://www. sm.ee/sites/default/files/content-editors/eesmargid_ja_tegevused/Tervis/Muud_infot/ suitsiidipreventsioon_esmatasandi_tervishoiutootajatele_ersi.pdf-12. november 2019).

Exline, Julie J. 2014. Getting Angry at God. Christian Reflection. A Series in Faith and Ethics. Waco, Texas: Institute for Faith and Learning at Baylor University (https://www. baylor.edu/content/services/document.php/235842.pdf - 12. november 2019).

Exline, Julie J. \& Rose, Ephraim 2005. Religious and spiritual struggles. Paloutzian, Raymond F. \& Park, Crystal L. (toim). Handbook of the psychology of religion and spirituality. New York: Guilford, lk 315-331.

Fitchett, George 2002. Assessing spiritual needs: a guide for caregivers. Minneapolis, MN: Augsburg.

Forcehimes, Alyssa A. \& Tonigan, J. Scott 2009. Spirituality and Substance Use Disorders. Huguelet, Philippe \& Koenig, Harold G. (toim). Religion and Spirituality in Psychiatry. Cambridge: Cambridge University Press, lk 548-549.

Frankl, Victor E. 2001. Mõttetahe. Valitud ettekandeid logoteraapiast. Tartu: Johannes Esto Ühing.

Galek, Kathleen \& Flannelly, Kevin J. \& Vane, Adam \& Galek, Rose M. 2005. Assessing a Patient's Spiritual Needs: A Comprehensive Instrument. Holistic Nursing Practice 19 (2), lk 62-69.

Grof, Christina 1994. The Thirst for Wholeness: Attachment, Addiction, and the Spiritual Path. New York: HarperCollins.

Grof, Stanislav 2008a. Spiritual Emergencies: Understanding and Treatment of Psychospiritual Crises. Reality Sandwich (http://realitysandwich.com/1800/spiritual_ emergencies/ - 12. november 2019).

Grof, Stanislav 2008b. Tuleviku psühholoogia. Tänapäevaseid teadvuse käsitlusi. Tartu: Väike Vanker.

Hay, David \& Hunt, Kate 2000. Understanding the Spirituality of People Who Don't go to Church. A report on the findings of the Adults' Spirituality Project at the University of Nottingham. Nottingham: Mission Theological Advisory Group (http://www. churchofscotland.org.uk/_data/assets/pdf_file/0006/3678/understanding_spirituality_ report.pdf - 4. november 2019).

Heelas, Paul 2013. Eesti kui katselabor - ideaalne näide vaimsuse ja religiooni suundumuste uurimiseks. Uibu, Marko (toim). Mitut usku Eesti III: Uue vaimsuse eri. Tartu: Tartu Ülikooli Kirjastus, lk 167-187. 
Hefti, René \& Gomes Esperandio, Mary Rute 2016. The Interdisciplinary Spiritual Care Model: A holistic Approach to Patient Care. Dossier: Religion and Health Horizonte, Belo Horizonte 14 (41), lk 13-47 (doi: 10.5752/P.2175-5841.2016v14n41p13).

Koenig, Harold G. 2012. Religion, spirituality, and health: the research and clinical implications. ISRN Psychiatry 2012/12 (doi: 10.5402/2012/278730).

Koenig, Harold G. \& McCullough, Michael E. \& Larson, David B. 2001. Handbook of religion and health. Oxford University Press.

Kulmar, Tarmo 1998. Eesti muinasusundi hingefenomenoloogia probleeme. Sator 1. Artikleid usundi- ja kombeloost. Tartu: Eesti Keele Instituudi rahvausundi töörühm, lk 38-49 (http://www.folklore.ee/rl/pubte/ee/sator/ - 12. november 2019).

Kroll, Jerome \& Sheehan, William 1981. Religious beliefs and practice among 52 psychiatric inpatients in Minnesota. American Journal of Psychiatry 146, lk 67-72 (doi: 10.1176/ajp.146.1.67).

Körtner, Ulrich H. J. 2016. Theological Perspectives and Integration of Religion and Spirituality into Health Care. Key note lecture on the 5th European Conference on Religion, Spirituality and Health, 12th to 14th of May 2016, Gdansk (http://www.ecrsh. eu/application/files/4014/6356/0086/Theological_Perspectives_and_Integration_of_ Religion_and_Spirituality_into_Health_Care_Ulrich_Koertner.pdf-12. november 2019).

Lake, James 2012. Spirituality and Religion in Mental Health: A Concise Review of the Evidence. Psychiatric Times, March, lk 34-38 (http://www.progressivepsychiatry.com/ PDF/PsychTimesReligion2012.pdf - 12. november 2019).

Lee, Bruce Y. \& Newberg, Andrew B. 2005. Religion and health: a review and critical analysis. Zygon. Journal of Religion \& Science 40 (2), lk 443-468 (doi: 10.1111/j.14679744.2005.00674.x).

Lehtsaar, Tõnu 2013. Sissejuhatus religioonipsühholoogiasse. Õpik kõrgkoolile. Tallinn: Eesti Keele Sihtasutus.

Linnuste, Indrek 2018. Spirituaalsus kui ressurss inimeste taastumisel ja rehabilitatsioonis. Sotsiaaltöö 2 (sotsiaaltöö ja sotsiaalpoliitika erialaajakiri), lk 80-97.

Lukoff, David 1998. From spiritual emergency to spiritual problem: The transpersonal roots of the new DSM-IV Category. Journal of Humanistic Psychology 38 (2), lk 21-50 (doi: 10.1177/00221678980382003).

Lukoff, David 2012. Altered States and Spiritual Awakening in Psychosis. Ettekanne konverentsil Consciousness in Crisis. An International Conference on Spiritual Crisis. 15. ja 16. september 2012, Holland.

Lukoff, David \& Lu, Francis G. \& Yang, C. Paul 2011. DSM-IV Religious and Spiritual Problems. Peteet, John R. \& Lu, Francis G. \& Narrow, William E. (toim). Religious and Spiritual Issues in Psychiatric Diagnosis. Arlington: American Psychiatric Publishing, lk 171-198.

MacLean, D. Charles \& Susi, Beth \& Phifer, Nancy \& Schultz, Linda \& Bynum, Deborah \& Franco, Mark \& Klioze, Andria \& Monroe, Michael \& Garrett, Joanne \& Cykert, Sam 2003. Patient preference for physician discussion and practice of spirituality. Journal of General Internal Medicine 18 (1), lk 38-43 (doi: 10.1046/j.1525-1497.2003.20403.x). 
Marin, Deborah B. \& Sharma, Vansh \& Powers, Richard \& Rev. Fleenor, David 2017. Spiritual Care and Physicians: Understanding Spirituality in Medical Practice. HealthCare Chaplaincy Network ja The Spiritual Care Association (https://www. healthcarechaplaincy.org/docs/about/hccn_whitepaper_spirituality_and_physicians. pdf - 11. november 2019).

Maslow, Abraham H. 1964. Religions, Values, and Peak Experiences. Columbus: Ohio State University Press.

McCarthy-Jones, Simon \& Waegeli, Amanda \& Watkins, John 2013. Spirituality and hearing voices: considering the relation. Psychosis, oktoober; 5 (3), lk 247-258 (doi: 10.1080/17522439.2013.831945).

McCord, Gary \& Gilchrist, J. Valerie \& Grossman, D. Steven \& King, D. Bridget \& McCormick Kenelm F. \& Oprandi, Allison M. \& Labuda Schrop, Susan \& Selius, A. Brian \& Smucker, William D. \& L. Weldy, David \& Amorn, Melissa \& A. Carter, Melissa \& J. Deak, Andrew \& Hefzy, Hebah \& Srivastava, Mohit 2004. Discussing Spirituality With Patients: A Rational and Ethical Approach. Annals of Family Medicine, Jul; 2 (4): lk 356-361 (doi: 10.1370/afm.7).

Meel, Liidia \& Linnuste, Indrek, \& Uibu, Marko 2016. Tervisevaldkonna spetsialistide arvamused ning kogemused spirituaalsuse, hingehoiu ja meditsiinilise pluralismi teemadel [Provisional overview of the survey 'Health-care specialists' opinions about and experiences with spirituality, pastoral care and medical pluralism]. The results are preserved in Tartu University Faculty of Theology, Tartu, Estonia.

Meel, Liidia 2017. Defining the context for best practices: Institutional setting for clinical pastoral care in Estonia. $J$ Relig Health 57 (1), lk 328-332 (doi: 10.1007/s10943-0170462-5).

Miller, William R. \& Forcehimes, Alyssa \& O'Leary, Mary \& LaNoue, Marnie D. 2008. Spiritual Direction in Addiction Treatment: Two Clinical Trials. Journal of Substance Abuse Treatment 35 (4), lk 434-442 (doi: 10.1016/j.jsat.2008.02.004).

Pargament, Kenneth I. 1997. The psychology of religion and coping: Theory, research, practice. New York: Guilford Press.

Pargament, Kenneth I. \& Cole, Brenda \& Vandecreek, Larry \& Belavich, Timothy \& Brant, Curtis \& Perez, Liza 1999. The vigil: Religion and the search for control in the hospital waiting room. Journal of Health Psychology 4, lk 327-341 (doi: 10.1177/135910539900400303).

Pargament, Kenneth 2007. Spiritually integrated psychotherapy. Understanding and Addressing the Sacred. New York, London: The Guilford Press.

Pargament, Kenneth \& Feuille, Margaret \& Burdzy, Donna 2011. The Brief RCOPE: Current Psychometric Status of a Short Measure of Religious Coping. Religions 2, lk 5-76 (doi: 10.3390/rel2010051).

Peteet, John R. \& Lu, Francis G. \& Narrow, William E (toim) 2011. Religious and Spiritual Issues in Psychiatric Diagnosis. Arlington: American Psychiatric Publishing.

Post, Brian C. \& Wade, Nathaniel G. 2009. Religion and Spirituality in Psychotherapy: A Practice Friendly Review of Research. Journal of Clinical Psychology 65 (2), lk 131-146 (doi: 10.1002/jclp.20563). 
Puchalski, Christina 2001. The Role of Spirituality in Health Care. Baylor University Medical Center Proceedings 14 (4), lk 352-357 (doi: 10.1080/08998280.2001.11927788).

Puchalski, Christina \& Romer, Anna 2000. Taking a Spiritual History Allows Clinicians to Understand Patients More Fully. Journal of Palliative Medicine 3 (1), lk 129-137 (doi: 10.1089/jpm.2000.3.129).

Randal, Patte \& Argyle, Nick 2005. 'Spiritual Emergency'- a useful explanatory model? A Literature Review and Discussion paper. London: Royal College of Psychiatrists (https://www.rcpsych.ac.uk/PDF/DrPRandalDrArgyleEmergency.pdf-2. oktoober 2018, see lehekülg ei ole enam kättesaadav).

Rüütel, Eha 2003. Tunnetatud sidusus tervise kontekstis. Eesti Arst 82 (8), lk 550-554 (https://eestiarst.ee/tunnetatud-sidusus-tervise-kontekstis/ - 12. november 2019).

Saad, Marcelo \& de Medeiros, Roberta 2012. Spiritual-Religious Coping - Health Services Empowering Patients' Resources. Saad, Marcelo (toim). Complementary therapies for the complementary healthcare. IntechOpen (doi: 10.5772/50443).

Saad Marcelo \& de Medeiros, Roberta 2016. Programs of religious/spiritual support in hospitals - five "Whies" and five "Hows". Philosophy, Ethics, and Humanities in Medicine 11 (5) (doi:10.1186/s13010-016-0039-z).

Scotton, Bruce W. 2011. Kundalini fenomenoloogia ja ravi. Scotton, Bruce W. \& Chinen, Allan B. \& Battista, John R. (toim) \& Kuri, Marie \& Mällo, Tanel (tlk). Transpersonaalse psühhiaatria ja psühholoogia tekstikogumik. Tallinn: Eesti Transpersonaalne Assotsiatsioon, lk 349-361.

Seligman, Martin \& Peterson, Christopher 2004. Character strengths and virtues: A handbook and classification. New York: Oxford University Press and Washington, DC: American Psychological Association.

Spinelli, Ernesto 2006. Existential psychotherapy: An introductory overview. Análise Psicológica 3 (XXIV), lk 311-321 (http://www.scielo.mec.pt/pdf/aps/v24n3/v24n3a04. pdf - 12. november 2019).

Uibu, Marko 2014. Inglid ja Inglipesa internetifoorum uue vaimsuse kandjate ja legitimeerijatena. Mäetagused 56, lk 181- 204 (doi: 10.7592/MT2014.56.uibu).

Vaitl, Dieter \& Birbaumer, Niels \& Gruzelier, John \& Jamieson, Graham A. \& Kotchoubey, Boris \& Kübler, Andrea \& Lehmann, Dietrich \& Miltner, Wolfgang H. R. \& Ott, Ulrich \& Pütz, Peter \& Sammer, Gebhard \& Strauch, Inge \& Strehl, Ute \& Wackermann, Jiri $\&$ Weiss, Thomas 2005. Psychobiology of Altered States of Consciousness. Psychological Bulletin by the American Psychological Association 131 (1), lk 98-127 (doi: 10.1037/00332909.131.1.98).

Williams, Joshua A. \& Meltzer, David \& Arora, Vineet M. \& Chung, Grace \& Curlin, Farr A. 2011. Attention to Inpatients' Religious and Spiritual Concerns: Predictors and Association with Patient Satisfaction. Journal of General Internal Medicine 26 (11), lk 1265-1271 (doi: 10.1007/s11606-011-1781-y).

Winter, Angela 2009. Across the Universe. Stanislav Grof On Nonordinary States Of Consciousness. The Sun, august (https://www.thesunmagazine.org/issues/404/acrossthe-universe - 2. oktoober 2018). 


\section{Lisa 1}

\section{Juhtumid}

Esimesed neli on illustreerivad juhtumid minu isiklikust praktikast (nimed ja kontekst on muudetud, kuid alles on jäetud spirituaalse kriisi ning seda põhjustanud kogemuse kirjeldused). Kõik isikud on elus hästi toimivad, pidanud kauakestvaid töösuhteid, peresuhteid ja sõprussuhteid, mis tavaliselt psüühiliste erivajadustega inimestel katkevad. Nende elukvaliteet on hea, ometi on need episoodid nende eluloos nagu teatud varjud, mis jälitavad neid ja mida paljud ei tea. Viimane kurb näide on meedia vahendatud, suhteliselt hiljuti ületas see uudisekünnised ning tekitas ohtralt diskussioone.

A. Holger (43) on jõustruktuurides vastutaval kohal töötav isik. Tema elus on mitmeid kummalisi episoode, kus ta on kokku puutunud paranormaalsete nähtustega. Juhtumeid, kus isikud haihtuvad ja/või muunduvad näiteks kakluse käigus teisteks olenditeks, on olnud mitu korda. Holger ei ole sellest peaaegu kellelegi rääkinud. Põhjuseks hirm töökoha kaotamise, väljanaermise ja skisofreenia diagnoosi ees. Vestluses usub ta siiralt, et maailmas on kurjad ja head jõud eraldatud ning tal on mingisugune roll selle lahendamisel.

B. Tiina (35) on riigiametnik, kes hakkas ühel hetkel tervislikult elama, loobus tasapisi nii alkoholist, nikotiinist kui ka loomsest toidust. Lisaks hakkas aktiivselt tegelema joogaga. Kogu eluviisi muutus kulmineerus psühhootilise episoodi ja ravile sattumisega. Kindlasti on taustal veel mitmeid muid tegureid, kuid olles ise tutvunud niinimetatud kundalini energia tõusmisega, saab seda psühhoosi ja haiglasse sattumist kirjeldada ning analüüsida ka kundalinipsühhoosina. Kahjuks haiglas ei osatud selle spirituaalse kriisi ilminguga edasi töötada ning patsient uuris ise interneti vahendusel oma sümptomeid ning jõudis kundalinipsühhoosi kirjelduseni.

C. Kaido (50) on kristliku koguduse juures tegutsev abivaimulik, kes viib läbi nii pühapäevakooli kui ka muid õpperinge. Elus palju lugenud, kogenud ja näinud mees. Kõrgete vaimsete võimetega. Kuid aegajalt satub ta alkoholitsüklisse ega tule toime oma eluga. Lisaks pingetele koguduse liikmete vahel, kus ta tunneb, et teda ei mõisteta, on tal ohtralt sisekonflikte oma käitumise silmakirjalikkuse pärast. Pidevad usus kahtlemised ja häbitunne. Ta on vahetanud väga mitmeid kogudusi, kui käinud "ennast otsimas" ka mitte-kristlikes liikumistes ja praktikates. 
D. Arvo (75) on aastaid tegelenud inimeste aitamisega. Ta on väikelinnas tuntud ravitseja, kelle poole pöörduvad inimesed kogu Eestist. Ometi on aegajalt tal tagasilöögid vaimse tervise mõttes. Meeleolu langeb, kaasneb kergesti ärritumine. Vestluses toob välja, et inimesed röövivad temalt energiat ning ta on väsinud teisi aitamast. Samas tõdeb, et see on tema elutöö. Anamneesist on teada ka enesetapukatseid.

E. Eestis on viimastel aastatel kogunud populaarsust konnamürgiseansid, mille korraldajad lubavad teadvuse avardumist ja isiklikele probleemidele kõiksuse abil lahenduse leidmist. Tegelikkuses võib oksendamise, kõhulahtisuse, südamepekslemise ja iiveldusega kulgeva seansi käigus ka surra, nagu juhtus mullu ühe konnamürgiusku pöördunud keskealise eesti mehega (54). (Allikas: Merilin Pärli. 02.10.2018 ERR, https://www.err.ee/865857/surm-konnamurgiseansilkeskealise-mehe-suda-seiskus - 12. november 2019).

\section{Summary}

\section{Religious and spiritual crisis in the context of mental health}

\section{Indrek Linnuste}

Doctoral student, School of Theology and Religious Studies

Faculty of Arts and Humanities, University of Tartu

indrek.linnuste@gmail.com

Keywords: mental health, religiosity, spiritual crisis, spiritual needs, spirituality

In addition to the biological body and psychological and social aspects, humans are spiritual beings. There is much in the world that we are yet unable to explain, but to what human experience reacts, either positively or negatively. This article treats the possible negative interpretations of spiritual experiences that manifest in different crises. Spirituality can be defined in various ways and it can, in turn, be divided into core categories that relate to human spiritual needs. In order to provide help that corresponds to the multidimensional human experience, it is important for health care to consider spiritual crises. Several of the spiritual crises entail good opportunities for personal development and therefore represent, in a hidden form, a potential for treatment and positive dynamics rather than psychopathology. Meanwhile, people outside the health care system would need to acknowledge the mental health problems that accompany spiritual experiences. There is a big risk of romanticizing several paranormal experiences or even mood shifts, which can result in the person not getting the needed help or treatment. Unfortunately, not even religious persons or those active in spiritual practices are immune to mental disorders. A growing interest in different New Age practices, which mix the search for fast spiritual experiences and solutions with several cultural and religious settings, quickly bring the downside of spirituality to the attention of mental health specialists. Spiritual needs are common to human experience and they often arise during illness and treatment. There are several methods for collecting information and 
spiritual history on the patient's needs, and sometimes simple questions asked during obtaining the medical history are sufficient to provide the specialist with necessary information that can be considered in developing the treatment plan. Changing the perspective can lead to a completely different understanding of the cause of several illnesses or disorders. As an example, a patient suffering from alcoholism can be seen as a person searching for connection or wholeness with higher forces. Spiritual issues are clinically related to the pathological risk that reminds us of the importance of including mental and existential issues in clinical practice. The religious/spiritual gap may become an obstacle. There is a considerable literature examining whether patients would prefer their physicians to inquire about their religious or spiritual beliefs as part of the routine history taking. Physicians maintain that the foremost reason they cannot provide spiritual care to patients is that they do not have enough time during the medical encounter. The second most common reason given is that they do not have adequate training to provide spiritual care to patients and that such care is better provided by others. Thirdly, physicians express discomfort about engaging in discussions on spirituality and faith with patients. In regard to the psychopathology of mental disorders, there are two basic classifications: the first one was created by the American Psychiatric Association (Diagnostic and Statistical Manual of Mental Disorders - DSM) and the second one was published by the World Health Organisation - WHO (The International Statistical Classification of Diseases and Related Health Problems - ICD). The development of the DSM, in its fourth edition, brought a change into the approach to religion and spirituality in the context of clinical diagnosis. Introducing V-code 62.89 (religious or spiritual problem) has increased the possibility of differential diagnosis between religion/spirituality and health/psychopathology. Unfortunately, there are no such developments in ICD-10. It sets boundaries to dealing with the R/S issues in psychiatry.

Indrek Linnuste on Tartu Ülikooli humanitaarteaduste ja kunstide valdkonna usuteaduskonna doktorant (magistrikraad psühholoogias ja terviseteaduses). On 15 aastat tegelenud psüühikahäiretega inimeste ning teiste haavatavatesse sihtrühmadesse kuuluvate ühiskonnaliikmetega. Doktorantuuris on tema uurimisvaldkonnaks spirituaalsed kriisid. Igapäevaselt juhib enda loodud sotsiaalset ettevõtet Solve et Coagula, mis pakub tööd puuduva ja vähenenud töövõimega inimestele. Tegeleb koolituste ja lektori tööga, peamiselt vaimse tervise ja sõltuvuste teemadel.

Indrek Linnuste is a $\mathrm{PhD}$ student at the School of Theology and Religious Studies, University of Tartu, Estonia, and has an MA degree in psychology and public health. He has been engaged in work with people with mental disorders and others in vulnerable target groups for 15 years. His current research field is spiritual crises. In 2013 he established a social enterprise Solve et Coagula, which offers work for people with diminished or without working ability. His daily work consists in trainings and educating, mainly on the topics of mental health and addictions.

indrek.linnuste@gmail.com 